\title{
Evaluation of the heme oxygenase-1 expression in esophagitis and esophageal cancer induced by different reflux experimental models and diethylnitrosamine ${ }^{1}$
}

\author{
Avaliação da expressão da Heme Oxigenase-1 em esofagite e câncer de esôfago induzidos por \\ diferentes modelos experimentais de refluxo e diethilnitrosamina
}

\author{
Cleber Rosito Pinto Kruel', Luis Felipe Ribeiro Pinto"I, Tania Cristina Moita Blanco ${ }^{\mathrm{III}}$, Theresa Christina Barja-Fidalgo ${ }^{\mathrm{IV}}$, Levi \\ Lourenzo Melov, Cleber Dario Pinto Kruel ${ }^{\mathrm{VI}}$
}

\author{
IMD, General Surgeon, Hospital de Clínicas de Porto Alegre, RS, Brazil. \\ ${ }^{\text {II }} \mathrm{PhD}$, Professor of Biochemistry, UERJ, Rio de Janeiro, Brazil. \\ III PhD, Fellow, UERJ, Rio de Janeiro, Brazil. \\ ${ }^{\text {Iv }} \mathrm{PhD}$, Associate Professor of Pharmacology, UERJ, Rio de Janeiro, Brazil. \\ ${ }^{v} \mathrm{MD}$, General Surgeon, UFRGS, Porto Alegre-RS, Brazil. \\ ${ }^{\mathrm{V}} \mathrm{PhD}$, Full Professor of Surgery, UFRGS, Porto Alegre-RS, Brazil.
}

\begin{abstract}
Purpose: To study the expression of heme-oxygenase-1 (HO-1), an enzyme induced by oxidative stress, in specimens obtained from an experimental model in rats that evaluated the role of gastric and duodenal reflux in esophageal carcinogenesis. Methods: Esophageal specimens embedded in paraffin obtained from different experimental groups of rats were used for immunohistochemistry analysis of HO-1 expression. The rats had been divided into the following groups and were killed after 22 weeks: (1) cardioplasty to induce acid reflux; (2) esophagoduodenal anastomosis to induce duodenal reflux; (3) no treatment; (4) cardioplasty + diethylnitrosamine (DEN); (5) esophagoduodenal anastomosis + DEN; and (6) DEN. The study sample comprised 3 specimens from each group with the most severe histopathological lesions found on each study branch. Results: The expression of HO-1 was seen only in rat specimens submitted to esophagoduodenal anastomosis (Groups 2 and 5), and the analysis of mean fluorescence intensity revealed a significant increase of HO-1 expression (4.8 and 4.6 fold, respectively) when compared with the control group (Group 3) ( $<<0.05$ ). The main target for HO-1 induction was the inflammatory cells inside the tumor or in subepithelial areas. Rats exposed to gastric reflux had no HO-1 expression. Conclusions: Reflux esophagitis induced by reflux of duodenal contents, which provoked considerable oxidative stress, may play an important role in esophageal carcinogenesis. Acid reflux did not induce oxidative stress in this experimental model.

Key words: Heme Oxygenase-1. Oxidative Stress. Esophageal Neoplasms. Rats.
\end{abstract}

\section{RESUMO}

Objetivo: Estudar a expressão da HO-1 (enzima induzida pelo estresse) em diferentes peças esofágicas obtidas de um estudo experimental em ratos que avaliou o papel do refluxo gastroesofágico e duodeno esofágico na carcinogênese experimental. Métodos: Blocos de parafina contendo peças de esôfago provenientes de um estudo experimental com ratos foram utilizados para verificar a expressão imunohistoquímica da HO-1. Os ratos haviam sido divididos nos seguintes grupos: (1) Cardioplastia com o objetivo de promover refluxo ácido, (2) Anastomose esofagoduodenal para indução de refluxo misto (ácido e biliar), (3) sem tratamento (controles), (4) cardioplastia + dietil-nitrosamina (DEN), (5) Anastomose esofagoduodenal + DEN, (6) DEN. Amostras contendo três peças de cada grupo com as lesões histopatológicas mais graves encontradas em cada braço do estudo foram escolhidas para avaliação da expressão imunoistoquímica da HO-1. Resultados: A expressão da HO-1 foi observada somente nas peças de esôfago de ratos submetidos à anastomose esofagoduodenal (Grupos 2 e 5) e analise da intensidade média da fluorescência demonstrou uma diferença significativa na expressão da HO-1 nesses grupos quando comparada com o grupo controle $(4,8$ e 4,6 vezes respectivamente) ( $p<0,05)$. As células inflamatórias localizadas dentro dos tumores e nas regiões adjacentes ao epitélio foram as que mais intensamente expressaram a HO-1. Ratos expostos ao refluxo ácido (gástrico) apresentaram pouca ou nenhuma atividade da HO-1. Conclusões: Esofagite de refluxo induzida pelo refluxo com conteúdo duodenal provocou considerável estresse oxidativo, que parece exercer um papel importante na carcinogênese esofágica. O refluxo puramente ácido não foi capaz de induzir estresse oxidativo nesse modelo experimental Descritores: Heme Oxigenase-1. Estresse Oxidativo. Neoplasias Esofágicas. Ratos.

${ }^{1}$ Research performed at Departments of Biochemistry and Pharmacology, State University of Rio de Janeiro (UERJ) and Post-graduate Program in Surgery, Federal University of Rio Grande do Sul (UFRGS), Brazil. 


\section{Introduction}

Esophageal cancer is the eighth most common cancer worldwide. It has received considerable attention in recent years because of the rapid increase of the adenocarcinoma histological subtype in Western countries ${ }^{1,2}$. The prognosis remains poor and the 5 -year survival rate is $10 \%{ }^{3}$. Therefore, it is important to understand the pathogenesis and develop strategies to prevent this deadly disease.

The development of esophageal adenocarcinoma follows a metaplasia-dysplasia-carcinoma sequence. Chronic reflux is a risk factor for esophageal metaplasia (Barrett's esophagus) and adenocarcinoma ${ }^{4,5}$. However, only $10 \%$ of individuals with reflux develop Barrett's esophagus (BE), and the estimated lifetime risk for a middle-aged individual with BE to develop adenocarcinoma is $10-15 \%{ }^{6,7}$. Factors other than acid reflux alone might also contribute to the progression from normal epithelia to BE and cancer. In patients with gastroesophageal reflux disease, the concentration of bile acids in the esophageal reflux correlates with the degree of esophageal mucosal injury ${ }^{8}$. Moreover, mixed reflux of gastric and duodenal juices is more common in patients with $\mathrm{BE}$ than in normal subjects ${ }^{8,9}$. The precise mechanisms by which duodenal reflux causes esophageal injury and cancer are unclear, but one of the driving forces may be oxidative stress ${ }^{10,11}$.

Chronic inflammation induced by biological, chemical and physical factors has been associated with increased risk of human cancer at various sites, including the esophagus ${ }^{12-15}$. One mechanism that may contribute to the development of esophageal cancer is the activation of inflammatory cells that induce and activate several oxidant-generating enzymes. These enzymes produce high concentrations of free radicals and oxidant species. Prolonged exposure to this environment may lead to host cell injury and DNA damage that might initiate tumor formation ${ }^{16}$.

Human cells, when exposed to chronic inflammation and oxidative stress, up-regulate anti-oxidant enzymes such as heme oxygenase-1 (HO-1), inducible nitric oxide synthase (iNOS) and cyclooxygenase-2 (COX-2). These enzymes may directly mediate inflammatory reaction or contribute to the resolution of inflammation $^{17,18}$. HO-1 plays a key role in cellular homeostasis as it catalyzes the first and rate-limiting step of heme degradation into equimolar amounts of carbon monoxide (CO), iron and biliverdin, which are subsequently reduced to bilirrubin ${ }^{19,20}$. HO-1 induction may be an adaptive cellular mechanism in response to oxidative stress. Growth and proliferation of various types of cells seem to be associated with HO-1 expression, and antiapoptotic and pro-angiogenic effects are two possible mechanisms implicated in this process ${ }^{21,22}$. Therefore, malignant behavior and HO-1 expression may be associated, and an elevated HO-1 activity has been found in cells of renal adenocarcinoma, lymphosarcoma, hepatoma, melanoma and squamous carcinoma ${ }^{23-26}$. A recent study demonstrated that HO-1 expression is progressively elevated following the sequence from normal oral epithelium to epithelia dysplasia and, finally, to squamous cell cancer in humans ${ }^{27}$. These findings reinforce the idea that oxidative stress may also play an important role in esophageal squamous cell carcinogenesis. HO-1 is expressed in esophageal cancer induced by duodenogastric reflux plus iron supplementation in rats ${ }^{28}$. However, the effect of acid reflux on induction of HO-1 expression in distal esophagus is not well understood.
This study investigated HO-1 expression in distal esophagus in different reflux experimental models ${ }^{29}$. It tested the hypothesis that acid reflux should be accompanied by duodenal juice to induce oxidative damage.

\section{Methods}

Tissue samples from experimental model of esophageal carcinogenesis in rats

A total of 100 Wistar rat esophageal specimens embedded in paraffin were available from a previous experimental study conducted in our institution to evaluate histopathological lesions caused by gastric and duodenoesophageal reflux, isolated or in association with diethylnitrosamine (DEN) in an experimental esophageal carcinogenesis mode ${ }^{29}$.

The rats were divided into five groups of 20 animals each, and a control group was formed with other 10 animals. Groups 1 and 4 comprised esophageal specimens obtained from rats submitted to a cardioplasty to induce gastroesophageal reflux. Gastroesophageal acid reflux was induced by a $6 \mathrm{~mm}$ longitudinal incision in all layers of the anterior esophagogastric junction, which was transversally sutured with 7-0 Prolene stitches similar to those used in the Heinecke-Mikulicz pyloroplasty (Figure 1A). An esophagoduodenostomy was performed in groups 2 and 5 to induce duodenoesophageal reflux into the distal esophagus. After the release of duodenum and the ligation of gastroesophageal junction, a 1-cm-long lateral esophagoduodenal anastomosis was performed with 6-0 Prolene stitches (Figure 1B). Operated animals in group 4 and 5, as well as a group that did not undergo any surgical intervention (Group 6), received a carcinogen, diethylnitrosamine (DEN) obtained from Sigma (St. Louis, MO, USA; N-nitrosodiethylamine, Sigma Chemical 0756) (100 ml flask, density $=0.95 \mathrm{~g} / \mathrm{ml}$, molecular weight 102.1 , chemical formula $=\mathrm{C} 4 \mathrm{H} 10 \mathrm{~N} 20)$. The carcinogen (DEN) was diluted in drinking water and administered to the animals at $5 \mathrm{mg} / \mathrm{kg} /$ day, considering a daily mean water consumption of $40 \mathrm{ml}$ per animal. Group 3 (10 rats) were not exposed to any treatment. This experimental study lasted 22 weeks and originated esophageal specimens embedded in paraffin that were classified into different histological stages in a study published by Melo et al. ${ }^{29}$.

Stage I: normal esophagus, light chronic esophagitis, low or moderate epithelial hyperplasia.

Stage II: marked epithelial hyperplasia, moderate or marked chronic esophagitis, papillomatosis, ulceration.

Stage III: Barrett's esophagus (intestinal metaplasia);

Stage IV: mild dysplasia

Stage V: moderate or marked dysplasia

Stage VI: adenocarcinoma or squamous cell carcinoma

According to the results previously published by Melo et $a{ }^{29}$ the following histopathological lesions were available for HO-1 immunochemistry analysis, divided in six different groups: Stage I)

Group 1 - Cardioplasty: 18 specimens (4 Stage II and 14

Group 2 - Esophagoduodenostomy: 18 specimens (2 Stage VI, 1 Stage III, 11 Stage II and 1 Stage I)

Group 3 - Tap Water (controls): 10 specimens (Stage I)

Group 4 - Cardioplasty + DEN: 17 specimens (10 Stage II and 7 Stage I) 
Group5 - Esophagoduodenostomy + DEN: 17 specimens (13 Stage VI and 4 Stage II)

Group 6 - DEN: 20 specimens (10 Stage II and 10 Stage I)
A

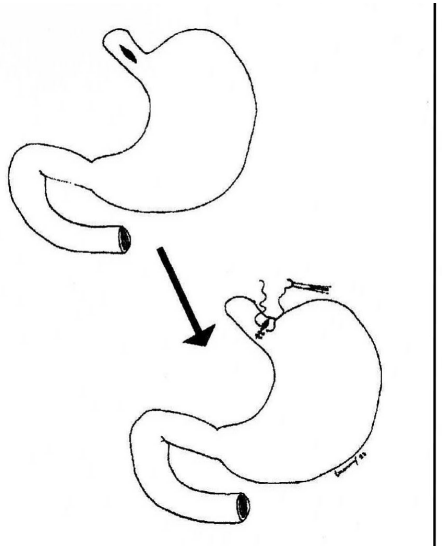

B

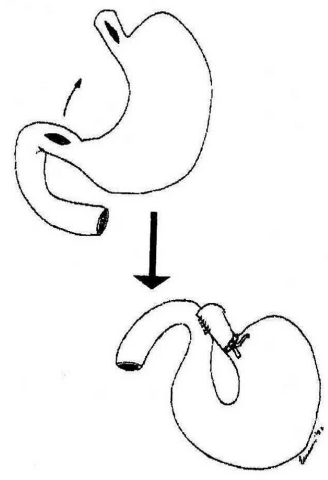

FIGURE 1 - Model of gastroesophageal reflux (cardioplasty) (A) and model of duodenoesophageal reflux (esophagoduodenostomy) (B)

Immunohistochemistry assay for HO-1 expression and quantification

HO-1 immunoreactivity was evaluated in a sample containing three different esophageal specimens from each group; the specimens selected had the most severe histopathological changes found in each experimental branch. This sample consisted of three esophageal specimens from group one with papillomatosis and ulceration (Stage II), two with adenocarcinoma (Stage VI) and one with columnar epithelium (Stage III) from group two, three control specimens (Stage I) from group three, three Stage II specimens from group four, three with squamous cell cancer (Stage VI) from group five, and three Stage II specimens from group six.

HO-1 expression was evaluated by immunohistochemistry. Paraffin sections $(4 \mu \mathrm{m})$ were cut, deparaffinized with xylene and rehydrated. Tissue sections mounted on glass were rehydrated in PBS with $0.1 \%$ Triton X-100 for 5 min, washed with PBS and incubated with $2 \%$ bovine serum albumin (BSA; Sigma Chem. Co, St. Luis, MO) followed by incubation with polyclonal anti-HO-1 antibody (1:50; Santa Cruz Biotechnology, Santa Cruz, CA, USA) overnight at 40 C. Subsequently, tissue slices were washed three times with PBS and incubated with biotin-conjugates anti-rabbit (1:50; Santa Cruz) followed by incubation with streptavidinconjugated FITC (1:50; Caltag Laboratories, Burlingame, CA, USA) for 1 hour at room temperature. Slides were mounted using a solution of $20 \mathrm{mM}$ propyl gallate and $80 \%$ glycerol in PBS. Microscopic analysis of images was performed using an epifluorescence microscope (Olympus BX40, Tokyo, Japan) equipped with appropriate filters.

Immunoreactivity to HO-1 was classified by two observers as positive (presence of cellular fluorescence) or negative (unspecific immunolabeling in keratin layer and absence of cellular fluorescence activity). Images were captured using a cooled-charged-coupled device camera (Photometrics, Tucson, AR, USA); the intensity of immune reaction was quantitatively assessed from original images using the Image-Pro Plus 4.0 software
(Media Cybernetics, Bethesda, MD, USA), and gray images were obtained using Adobe Photoshop software (Adobe, San José, CA, USA).

\section{Statistical analysis}

The Fisher exact and the chi square tests were used for statistical analyses. Statistical significance was set at $\mathrm{p}<0.05$.

\section{Results}

Correlation between HO- 1 expression and histopathological features

Groups that were not exposed to duodenal contents did not show HO-1 immunoreactivity in the esophagus. Even when Stage II grade lesions were examined, no HO-1 cell expression was observed in groups one, two, four and six (Figures 2 and 3). In all sections from rats submitted to esophagoduodenal anastomosis (Groups 2 and 5), the results from analysis of mean fluorescence intensity revealed a significant increase of HO-1 expression (4.8 and 4.6 fold, respectively) (Figure 2) when compared with controls (Group 3). These values were similar to mean fluorescence intensity analyzed in tumor slices (5.5 fold) (Figure 2). To identify the cells with HO-1 immunoreactivity, the same esophageal area in $\mathrm{HE}$ and immunofluorescence labeled slices were examined simultaneously. The comparison of samples revealed that positive HO-1 expression was not uniformly distributed in tissue slices. HO-1 expression was found in inflammatory cells (macrophages, eosinophils and lymphocytes) directly beneath the epithelium or in erosion areas. Squamous cell epithelium did not express HO-1 as observed in adjacent areas with intense inflammatory cells (Figure 4). All HO-1 immunoreactivity was distributed in the distal one-third or two-thirds of the esophagus and no immunoreactivity was found in the upper one-third of the esophagus, not even in the animals with adenocarcinoma.

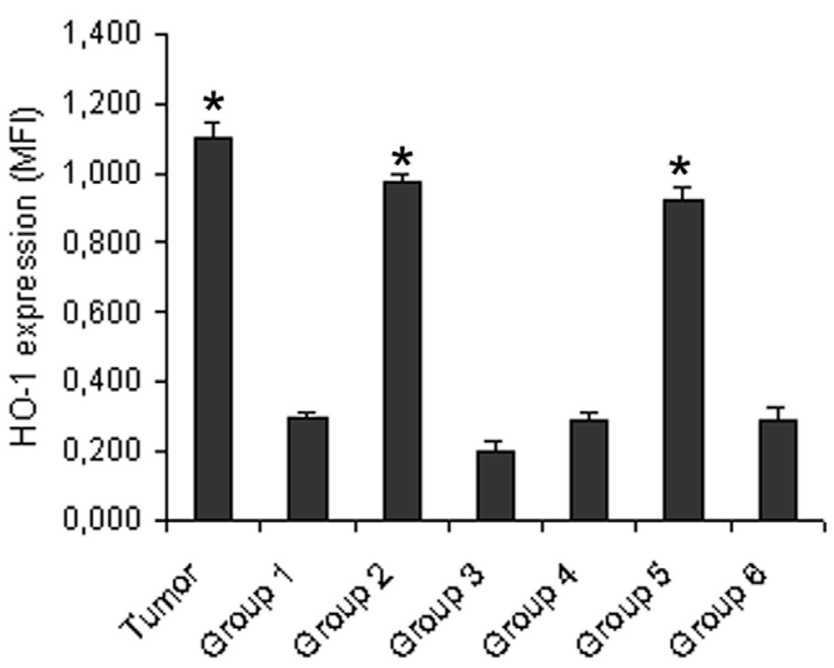

FIGURE 2 - Mean fluorescence intensity of HO-1 expression in esophageal tissue slices from different experimental models of reflux. Tissue slices were immunolabeled for HO-1 and visualized by fluorescence microscopy; fluorescence intensity was analyzed using Image-Pro Plus 4.0 software. Measures of fluorescence intensity are presented as mean + SD from three samples in each group. ${ }^{*} \mathrm{p}<0.05$ vs. control values 

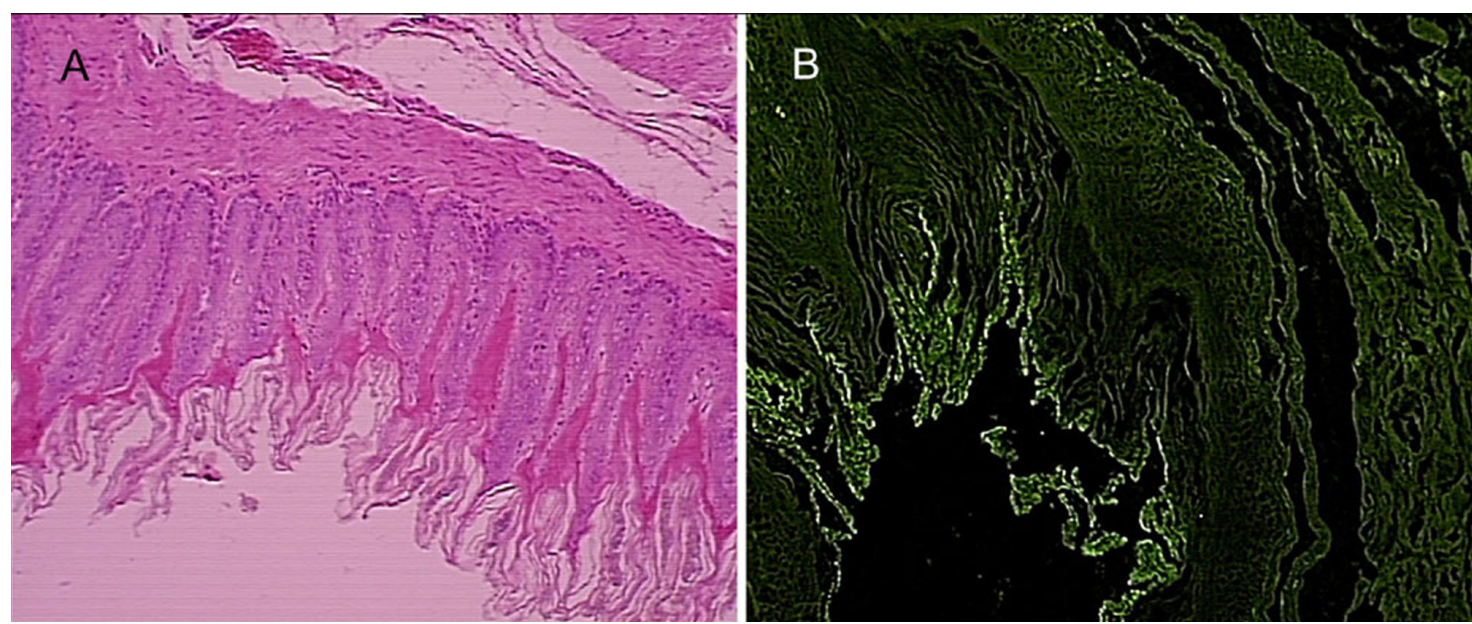

FIGURE 3 - Histological analysis and HO-1 expression in esophageal tissue slice shows papillary hyperplasia in rats exposed to gastroesophageal reflux plus DEN. Tissue slices were stained for histology (A) and immunohistochemistry for HO-1 (B). Unspecific immunolabeling was seen in keratin layer. No significant staining was detected in epithelial or subepithelial areas. Magnification: 100x
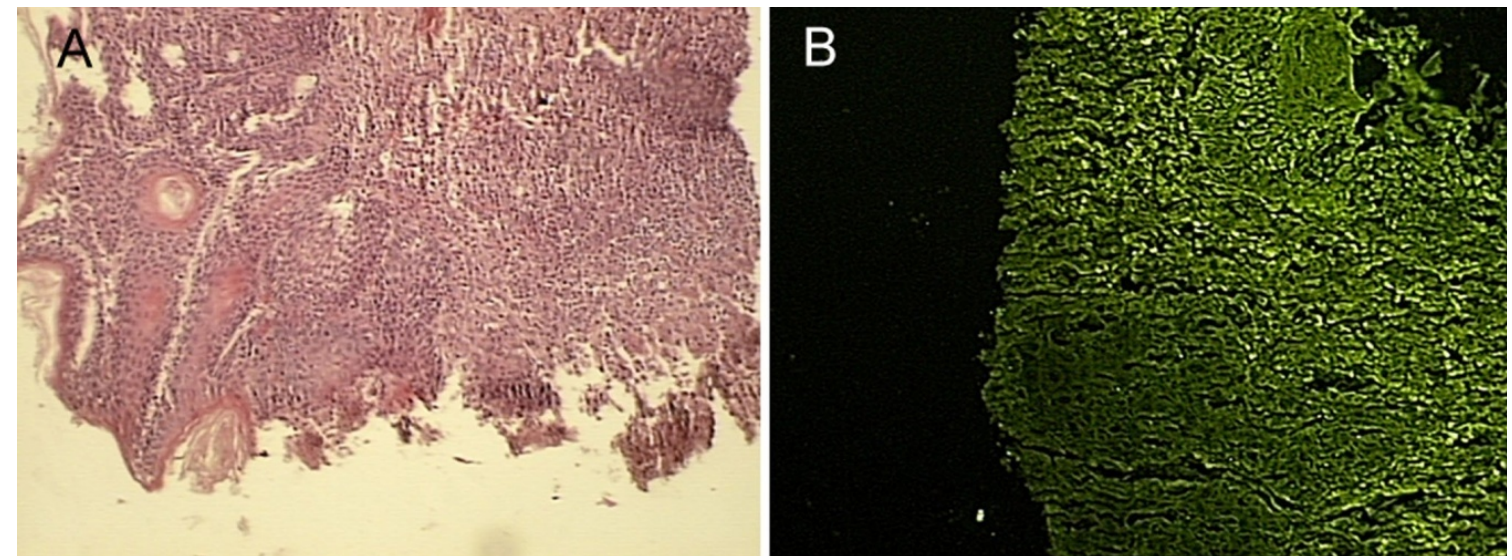

FIGURE 4 - Histological analysis and HO-1 expression in esophageal tissue slice with squamous esophageal epithelia from a rat exposed to duodenoesophageal reflux. Squamous esophageal epithelia and adjacent erosion with severe esophagitis (A). HO-1 expression was intense in erosion inflammatory cells and also in subepithelial inflammatory infiltrate below squamous cell epithelia (B). Arrows indicate HO-1 labeling in erosion and subepithelial areas. Magnification: $200 \mathrm{x}$

In adenocarcinoma tissue slices, HO-1 was expressed in glandular cells and also in tumoral stroma, but the main immunoreactivity was detected in macrophages and other inflammatory cells (eosinophils and lymphocytes) (Figure 5). Severe inflammation and high HO-1 expression in inflammatory infiltrate (Figure 4) were found also in areas without tumor cells in esophageal tissue from animals exposed to duodenal reflux. However, squamous cell epithelium did not express HO-1 in esophageal tissue with adenocarcinoma. The same profile was observed in tissue with squamous cells carcinoma, where HO-1 expression was intense in inflammatory cells, but not in tumor cells. 

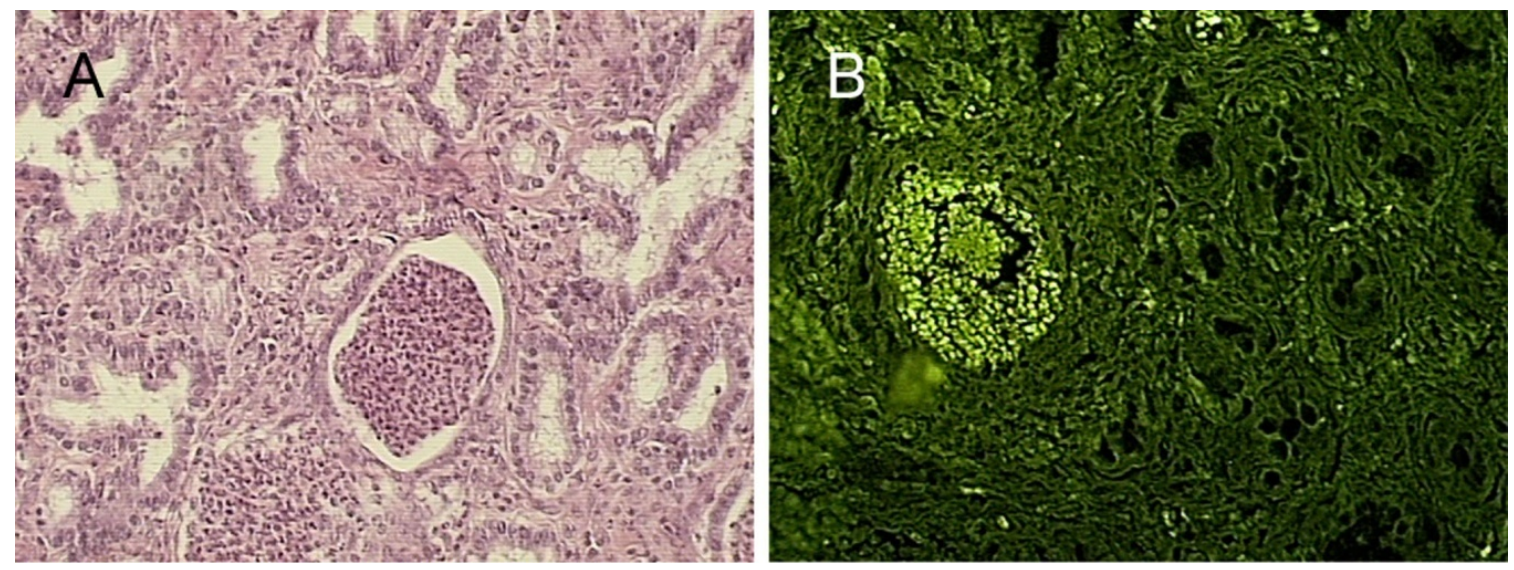

FIGURE 5 - Histological analysis and HO-1 expression in esophageal tissue slice with adenocarcinoma from rats exposed to duodenoesophageal reflux. Micrograph (A) shows adenocarcinoma with intense inflammatory infiltrate. HO-1 was highly expressed in almost the same area in inflammatory infiltrate cells in glandular arrangement (B). Magnification: 200x

In addition, when samples from animals exposed to acid reflux were analyzed together $(\mathrm{n}=6)$ and samples from those exposed to duodenal juice as another group $(n=6)$, HO-1 expression was significantly different between these two types of reflux models $(\mathrm{p}<0.05$; Table 1$)$.

TABLE 1 - Correlation between histopathological features and HO-1 expression in distal esophagus in different reflux experimental models

\begin{tabular}{ccc}
\hline Groups & Histopathological Analysis & HO-1 expression \\
\hline Group 1: Gastroesophageal reflux $(\mathrm{n}=3)$ & 1-Stage II; 2-Stage II; 3-Stage II & All negative \\
Group 2: Duodenoesophageal reflux $(\mathrm{n}=3)$ & 1-Stage III; 2-Stage VI; 3-Stage VI & All positive \\
Group 3: Control $(\mathrm{n}=3)$ & 1-Stage I; 2-Stage I; 3-Stage I & All negative \\
Group 4: Gastroesophageal reflux plus DEN $(\mathrm{n}=3)$ & 1-Stage II; 2-Stage II; 3-Stage II & All negative \\
Group 5: Duodenoesophageal reflux plus DEN $(\mathrm{n}=3)$ & 1-Stage VI; 2-Stage VI; 3-Stage VI & All positive \\
Group 6: DEN $(\mathrm{n}=3)$ & 1-Stage II; 2-Stage II; 3-Stage II & All negative \\
\hline
\end{tabular}

\section{Discussion}

Despite advances in the understanding of the association between esophageal adenocarcinoma and gastroesophageal reflux, few studies have investigated their underlying causes. Studies have shown that duodenogastric reflux per se causes intestinal metaplasia and adenocarcinoma in rats, even without exposure to carcinogens ${ }^{29,30}$. In contrast, gastric contents do not induce this metaplasia-carcinoma sequence ${ }^{31}$. Moreover, esophageal exposure to a mixed type of reflux containing gastric and duodenal juices has been implicated in the development of Barrett's esophagus, and this may explain why some patients do not progress to metaplasia and cancer $^{8,9}$. Although the precise mechanisms by which reflux of duodenal contents causes esophageal injury and predisposes to neoplasia are not completely understood, there is considerable evidence that chronic inflammation and oxidative damage may play a role in this type of tissue injury ${ }^{11,15}$.

Reactive oxygen species (ROS), superoxide anion $\left(\mathrm{O}_{2}^{-}\right)$, hydrogen peroxide, hydroxyl radicals and nitric oxide (NO) are oxidant molecules constantly generated in vivo and known to be implicated in signaling pathways regulating cell growth and cell redox control. However, they might be produced in excess in chronic inflammatory processes and, thus, exert detrimental effects, such as lipid peroxidation and DNA damage. The progression of oxidative stress damage has been implicated in human cancer ${ }^{27,32}$. In distal esophagus, Sihvo et al. ${ }^{15}$ observed that the reflux diseasemetaplasia-carcinoma sequence revealed progressively increased oxidative stress, which suggested a link between oxidative damage and malignant transformation of esophageal epithelium. 
Under physiological conditions, tissues do not express $\mathrm{HO}-1$, an adaptive response to protect cells from oxidative damage. Data suggest that this important cytoprotective effect also occurs in tumor cells because of anti-apoptotic and angiogenic properties $^{21,26}$. In our study, rats exposed to duodenal reflux developed cancer and expressed HO-1 in a pattern similar to the one found by Chen et al. ${ }^{28}$ the less intense glandular cell immunoreactivity seen in our study might be attributed to the fact that we did not offer any iron supplements to the rats. As inflammatory areas with high HO-1 expression were found far from malignant lesions, we agree with other authors that the progression of esophagitis-metaplasia-adenocarcinoma sequence is associated with oxidative stress ${ }^{15}$. However, the histological changes seen in animals exposed to acid reflux were less severe than those in animals exposed to additional duodenal reflux, and it was clear that acid reflux was not sufficient to induce significant oxidative stress in this experimental model. Thus, the difference in HO-1 expression in these two models of reflux might explain why acid reflux did not induce esophageal adenocarcinoma.

Although gastroesophageal reflux disease has not been associated with squamous cell carcinoma of the esophagus ${ }^{33}$, studies with rats have shown that duodenal content reflux into the esophagus induces squamous cell dysplasia and adenocarcinoma in the same way as when a co-carcinogen and a carcinogen are given simultaneously ${ }^{30,34,35}$. In addition, chronic thermal injury of the esophagus caused by hot beverage abuse may be involved in esophageal cancer, as demonstrated in an experimental study and a population area ${ }^{36,37}$. Accordingly, our results suggest that the chronic inflammatory process mediated by duodenal reflux may play a role in the development of squamous cell carcinoma.

\section{Conclusion}

Duodenal reflux may act as a co-carcinogen in esophageal squamous cell pathogenesis in rats, which may be mediated by oxidative stress, as suggested by HO-1 expression during histological malignant transformation. Additional studies should focus on oxidative stress, because HO-1 may be a useful biomarker of risk factor for malignant progression.

\section{References}

1. Blot WJ, Devesa SS, Kneller RW, Fraunemi JF Jr. Rising incidence of adenocarcinoma of the esophagus and gastric cardia. JAMA. 1991;265:1287-9.

2. Greenlee RT, Hill-Harmon MB, Murray T, Thun M. Cancer Statistics, 2001. CA Cancer J Clin. 2001;51:15-36.

3. Farrow DC, Vaughan TL. Determinants of survival following the diagnosis of esophageal adenocarcinoma. Cancer Causes Control. 1996;7:322-7.

4. DeMeester SR, Peters JH, DeMeester TR. Barrett esophagus. Curr Probl Surg. 2001;38:558-640.

5. Buttar NS, Falk GW. Pathogenesis of gastroesophageal reflux and Barrett esophagus. Mayo Clin Proc. 2001;76:226-34.

6. Campos GM, DeMeester SR, Peters JH, Öberg S, Crookes PF, Hagen JA, Bremner CG, Sillin III LF, Mason RJ, DeMeester TR. Predictive factors of Barrett esophagus: multivariate analysis of 502 patients with gastroesophageal reflux disease. Arch Surg. 2001;136:1267-73.

7. Wild CP, Hardie LJ. Reflux, Barrett's oesophagus and adenocarcinoma: burning questions. Nat Rev Cancer. 2003;3:676-84.
8. Nehra D, Howell P, Williams CP, Pye JK, Beynon J. Toxic bile acids in gastro-oesophageal reflux disease: influence of gastric acidity. Gut. 1999;44:598-602.

9. Kauer WK, Peters JH, DeMeester TR, Ireland AP, Bremner CG, Hagen JA. Mixed reflux of gastric and duodenal juices is more harmful to the esophagus than gastric juice alone. The need for surgical therapy re-emphasized. Ann Surg. 1995;222:525-33.

10. Farhadi A, Fields J, Banan A, Keshavarzian A. Reative oxygen species: are they involved in the pathogenesis of GERD, Barrett's esophagus, and latter's progression toward esophageal cancer? Am J Gastroenterol. 2002;97:22-6.

11. Lee JS, Oh TY, Ahn BO, Cho H, Kim WB, Kim YB, Surh YJ, Kim HJ, Hahm KB. Involvement of oxidative stress in experimentally induced reflux esophagitis and Barrett's esophagus: clue for the chemoprevention of esophageal carcinoma by antioxidants. Mutat Res. 2001;480-481:189-200. 12. Colllins RH, Feldman M, Fordtran JS. Colon cancer, dysplasia and surveillance in patients with ulcerative colitis. A critical review. N Engl J Med. 1987;136:1654-8.

13. Shimoda R, Nagashima M, Sakamoto M, Yamaguchi N, Hirohashi S, Yokota J, Kasai H. Increased formation of oxidative DNA damage, 8-hydroxydeoxyguanosine, in human livers with chronic hepatitis. Cancer Res. 1994;54:3171-2.

14. Holzinger F, Z'graggen K, Büchler MW. Mechanisms of biliary carcinogenesis: a pathogenic multi-stage cascade towards cholangiocarcinoma. Ann Oncol. 1999;10(Suppl)4:122-6.

15. Sihvo EI, Ruohtula T, Auvinen M, Koivistoinen A, Harjula AL, Salo JA. Simultaneous progression of oxidative stress and angiogenesis in malignant transformation of Barrett esophagus. J Thorac Cardiovasc Surg. 2003;126:1952-7.

16. Ohsima H, Tatemichi M, Sawa T. Chemical basis of inflammationinduced carcinogenesis. Arch Biochem Biophys. 2003;417:3-11.

17. Vane JR, Mitchell JA, Appleton I, Tomlinson A, Bishop-Bailey D, Croxtall J, Willoughby DA. Inducible isoforms of cycloxygenase and nitric oxide synthase in inflammation. Proc Natl Acad Sci USA. 1994;91:2046-50.

18. Willis D, Moore AR, Willoughby DA. Heme oxygenase isoform expression in cellular and antibody-mediated models of acute inflammation in the rat. J Pathol. 2000;190:627-34.

19. Tenhunen R, Marver HS, Schimidt R. The enzymatic conversion of heme to bilirubin by microsomal heme oxygenase. Proc Natl Acad Sci USA. 1968;61:748-55.

20. Morse D, Choi AM. Heme-oxygenase: The "emerging molecule" has arrived. Am J Resp Cell Mol Biol. 2002;27:8-16.

21. Fang J, Akaike T, Maeda H. Antiapoptotic role of heme oxygenase (HO) and the potential of $\mathrm{HO}$ as a target in anticancer treatment. Apoptosis. 2004;9:27-35

22. Sunamura M, Duda DG, Ghattas MH, Lozonschi L, Motoi F, Yamauchi J, Matsuno S, Shibahara S, Abraham NG. Heme-oxygenase-1 accelerates tumor angiogenesis of human pancreatic cancer. Angiogenesis. 2003;6:15-24. 23. Goodman AI, Choudhury M, da Silva JL, Schwartzman ML, Abraham NG. Overexpression of the heme oxygenase gene in renal cell carcinoma. Proc Soc Exp Biol Med. 1997;214:54-61.

24. Tsuji MH, Yanagawa T, Iwasa S, Tabuchi K, Onizawa K, Bannai S, Toyooka H, Yoshida H. Heme oxygenase-1 expression in oral squamous cell carcinoma as involved in lymph node metastasis. Cancer Lett. 1999;138:53-9.

25. Torisu-Itakura H, Furue M, Kuwano M, Ono M. Co-expression of thymidine phosphorylase and heme oxygenase- 1 in macrophages in human malignant vertical growth melanomas. Jpn J Cancer Res. 2000;91:906-10.

26. Doi K, Akaike T, Fujii S, Tanaka S, Ikebe N, Beppu T, Shibahara S, Ogawa M, Maeda H. Induction of haem oxygenase-1 by oxide nitric and ischeamia in experimental solid tumours and implications for tumour growth. Br J Cancer. 1999;80:1945-54. 
27. Lee J, Lee SK, Lee BU, Lee HJ, Cho NP, Yoon JH, Choi HR, Lee SK, Kim EC. Upregulation of heme oxygenase-1 in oral ephithelial dysplasias. Int J Oral Maxillofac Surg. 2008;37:287-92.

28. Chen X, Ding YW, Yang G, Bondoc F, Lee MJ, Yang CS. Oxidative damage in an esophageal adenocarcinoma model with rats. Carcinogenesis. 2000;21:257-63.

29. Melo LL, Kruel CD, Kliemann LM, Cavazzola LT, Boeno Rda L, Silber PC, Grossi RS. Influence of surgically induced gastric and gastroduodenal content reflux on esophageal carcinogenesis- experimental model in Wistar female rats. Dis Esophagus. 1999;12:106-15.

30. Goldstein SR, Yang GY, Curtis SK, Reuhl KR, Liu BC, Mirvish SS, Newmark HL, Yang CS. Development of esophageal metaplasia and adenocarcinoma in rat surgical model without the use of a carcinogen. Carcinogenesis. 1997;18:2265-70.

31. Miwa K, Sahara H, Segawa M, Kinami S, Sato T, Miyazaki I, Hattori T. Reflux of duodenal or gastro-duodenal contents induces esophageal carcinoma in rats. Int J Cancer. 1996;67:269-74.

32. Cejas P, Casado E, Belda-Iniesta C, De Castro J, Espinosa E, Redondo A, Sereno M, Garcia-Cabezas MA, Vara JA, Domínguez-Cáceres A, Perona R, González-Barón M. Implications of oxidative stress cell membrane lipid peroxidation in human cancer (Spain). Cancer Causes Control. 2004; $15: 707-19$.

33. Lagergren J, Bergström R, Lindgren A, Nyrén O. Symptomatic gastroesophageal reflux as risk factor for esophageal adenocarcinoma. $\mathrm{N}$ Engl J Med. 1999;340:825-31.

34. Pera M, Cardesa A, Bombi JA, Ernst H, Pera C, Mohr U. Influence of esophagojejunostomy on the induction of adenocarcinoma of the distal esophagus in Sprague-dawley rats by subcutaneous injection of 2,6-dimethylnitrosomorpholine. Cancer Res. 1989;49:6803-8.

35. Jang TJ, Min SK, Bae JD, Jung KH, Lee JI, Kim JR, Ahn WS. Expression of cyclooxygenase 2, microsomal prostaglandin E synthase 1, and EP receptors is increased in rat oesophageal squamous cell dysplasia and Barrett's metaplasia induced by duodenal contents reflux. Gut. 2004;53:27-33.

36. Victora CG, Muñoz N, Day NE, Barcelos LB, Peccin DA, Braga NM. Hot beverages and oesophageal cancer in southern Brazil: a case-control study. Int J Cancer. 1987;39:710-6.

37. Castellsagué X, Muñoz N, De Stefani E, Victora CG, Castelletto R, Rolón PA. Influence of hot mate drinking, hot beverages and diet on esophageal cancer risk in South America. Int J Cancer. 2000;88:658-64.

Conflict of interest: none Financial source: none

\section{Correspondence:}

Cleber Rosito Pinto Kruel

Rua Ramiro Barcelos, 910/701

90035-001 Porto Alegre - RS Brazil

Phone: (55 51)3311-4477 / 9912-9705

kruelrosito@yahoo.com.br

Received: December 14, 2009

Review: February 18, 2010

Accepted: March 15, 2010

\section{How to cite this article}

Kruel CRP, Pinto LFR, Blanco TCM, Barja-Fidalgo TC, Melo LL, Kruel CDP. Evaluation of the heme oxygenase-1 expression in esophagitis and esophageal cancer induced by different reflux experimental models and diethylnitrosamine. Acta Cir Bras. [serial on the Internet] 2010 May-June;25(3). Available from URL: http://www.scielo.br/acb 